


\title{
HUMANISME SPIRITUAL: Konseptualisasi dan Performansi Melalui Pendidikan Islam
}

\section{Prabowo Adi Widayat}

Mahasiswa Doktor Universitas Islam Negeri (UIN) Sunan Kalijaga Yogyakarta.

Jl. Laksda Adisucipto, Caturtunggal, Kecamatan Depok, Kabupaten Sleman, Daerah Istimewa Yogyakarta 55281.

E-mail: Mahabbatullah10@gmail.com

\begin{tabular}{|c|c|c|}
\hline Diterima: & Revisi: & Disetujui: \\
20 Maret 2018 & 20 April 2018 & 03 Juni 2018 \\
\hline
\end{tabular}

\begin{abstract}
Humanism rooted and growing in every human life is a conceptual mission humanity in space and time. Humanism always brings the concept of alignment, honor, and dignity of human beings in various dimensions to understand his position and implemented in the social life. Spirituality is an urge from within human sourced from a deep spiritual side. He is abstract and made life path combined with elements of religious and socio-cultural values rooted stronger. Spiritual humanism is a humanitarian concept which represents a side of distinctiveness, uniqueness, advantages and disadvantages that exist in human beings by referencing only at teoantropocentric which makes aspects divinity of Allah SWT with all its affordability and man with the potential to make it more meaningful and meaningless in the course of an increasingly complex life obstacles. Islamic education became an important locomotive in the embodiment of spiritual humanism within the framework of theoretical or scientific knowledge of Islam and is pragmatic in the vertical and horizontal form of worship.
\end{abstract}

Keyword: Spiritual Humanism, Teoantropocentric, and Islamic Education

\begin{abstract}
Abstrak
Humanisme yang mengakar dan tumbuh di setiap kehidupan manusia merupakan misi konseptual kemanusiaan yang berada dalam ruang dan waktu. Humanisme senantiasa mengusung konsep kesejajaran, kehormatan, harkat dan martabat manusia dalam beragam dimensi untuk dimengerti
\end{abstract}


kedudukannya dan diimplementasikan dalam kehidupan bermasyarakat. Spiritualitas merupakan dorongan internal manusia yang bersumber dari sisi kerohanian yang mendalam. Ia bersifat abstrak dan dijadikan jalan hidupan yang dipadukan dengan unsur-unsur keagamaan yang kokoh dan nilai-nilai sosiokultural yang mengakar kuat. Humanisme spiritual merupakan konsep kemanusiaan yang merepresentasikan sisi kekhasan, keunikan, kelebihan dan kekurangan yang ada pada diri manusia dengan berkiblat pada teoantroposentris yang menjadikan aspek ketuhanan Allah SWT dengan segala kemahaannya dan manusia dengan potensi yang dimilikinya untuk menjadikannya lebih berarti dan bermakna dalam perjalanan kehidupan yang semakin kompleks rintangannya. Pendidikan Islam menjadi lokomotif penting dalam pengejawantahan humanisme spiritual dalam kerangka teoritik atau keilmuan Islam dan secara pragmatik dalam bentuk ibadah vertikal dan horizontal..

Kata Kunci: Humanisme Spiritual, Teoantroposentris, Pendidikan Islam

\section{A. Pendahuluan}

Kejiwaan manusia pada dasarnya memiliki dua dimensi yang saling mengiringi yakni secara mandiri dan kolektif. Kejiwaan secara mandiri dimanfestasikan melalui sikap beragama secara privat. Hal ini didasarkan bahwa seseorang melakukan aktivitas beragamanya untuk memperoleh ketenangan dan kenyamanan batin secara baik dan benar dengan memantapkan arah hidup yang sedang dijalani. Adapun kejiwaan secara kolektif dimanifestasikan melalui pemberdayaan setiap individu sebagai bagian terpenting dalam penciptaan dan pengelolaan kehidupan sosial yang baik, bermartabat, dan penuh kesejahteraan sehingga menjadikan suasana kehidupan bermasyarakat menjadi lebih kondusif. Oleh karena itu, antara kejiwaan secara mandiri dan kolektif tentunya menjadi aspek fundamental untuk merancang, membangun dan menghiasi kehidupan seseorang menjadi lebih berwarna, bervariasi dan bermartabat dengan mengintegrasikan sisi normativitas agama, nilai-nilai kehidupan berbangsa dan bernegara, dan ilmu pengetahuan sebagai penerang dan penjelas bagi ketidakteraturan yang saling menghampiri.

Spiritualitas menjadi sebuah paradoks di kalangan umat manusia. Karena mereka secara eksplisit sering kali memperlihatkan tidak 
adanya eksistensi spiritualitas dalam kehidupan yang multidimensi ini disebabkan oleh suatu dan alasan tertentu. Spiritualitas tentunya harus mengejawantah dalam tindak tutur kehidupan sehari-hari dan pola pikir yang sehat dengan memperhatikan nilai sosial, agama, dan aspek pengetahuan ilmiah yang baik dalam suatu ajaran agama atau ajaran-ajaran kehidupan yang menjadi konsensus suatu masyarakat atau komunitas tertentu. Di sisi lain, spiritualitas menjadi rapuh dan tidak bernyawa apalagi berjasad ketika berhadapan dengan serangkaian perilaku umat manusia yang menjadikan materi sebagai tolok ukur keberhasilan atau kesuksesan dalam suatu aspek kehidupan. Oleh karena itu, untuk mengokohkan aspek spiritualitas tersebut tentunya bangunan kemanusiaan harus menjadi sorotan utama untuk memperoleh manusia-manusia spiritual yang religius dan bermartabat.

Pendidikan Islam menjadikan spiritualitas yang kokoh sebagai cerminan dan landasan di setiap pembelajaran. Spiritualitas yang dimaksudkan dalam hal ini adalah relasi ilahiyyah dalam kerangka ibadah amaliyah yang dimanifestasikan melalui interaksi simbolik dan mutualistik antara guru dan siswa dalam pembelajaran, antara peraturan sekolah dengan perilaku siswa, guru, dan pengelola sekolah serta antara materi pelajaran dan siswa sebagai pengkajinya serta guru sebagai transmiternya. Spiritualitas secara universal dihayati dan diimplementasikan oleh setiap individu tentunya berimplikasi pada mekanisme penataan kehidupan menjadi lebih teratur dan kondusif. Suasana kebatinan yang nyaman menjadi tonggak terselenggaranya pengelolaan peradaban kehidupan yang lebih dinamis. Oleh karena itu, spiritualitas bukanlah persoalan teologis semata yang sarat dengan absolutisme tanpa kompromi namun persoalan teologis fungsional yang memadu dalam tindak tutur yang manusiawi dengan dilandasi oleh sifat ketuhanan yang maha pengasih dan penyayang bagi seluruh alam semesta.

Humanisme pada dasarnya adalah instrumen bangunan konsep kemanusiaan universal dalam lingkaran kehidupan yang dinamis. Ia menempati ruangan-ruangan ide dan tindakan dalam diri setiap 
manusia ketika ia memposisikan dirinya sebagai pengelola, penjaga, dan pengayom alam semesta secara baik dan benar. Humanisme sejatinya hadir dalam sistem kognisi dan afeksi manusia yang telah diasah dengan keilmuan yang proporsional dan dilandasi oleh ajaranajaran agama yang hanīf. Oleh karena itu, implementasi humanisme adalah dengan memberdayakan potensi-potensi yang dimiliki manusia untuk membangun rumah peradaban yang di dalam terdapat beberapa yang utama yakni kesejahteraan, keramahtamahan, saling menghormati dalam segala perbedaan yang mengemuka, dan mewujudkan perdamaian yang hakiki untuk menghasilkan manusiamanusia baik dan berguna bagi alam semesta. ${ }^{1}$

Humanisme spiritual yang akan dibahas melalui tulisan ini bertujuan untuk dijadikan konsep bangunan kemanusiaan yang berkiblat pada lini teoantroposentris yakni menjadikan aspek ketuhanan dengan segala kemahaannya dan manusia dengan potensi yang dimilikinya untuk menjadikannya lebih berarti dan bermakna dalam perjalanan kehidupan yang semakin kompleks rintangannya. Selain itu juga, humanisme spiritual dapat dijadikan pijakan teoritik atau konseptual dalam penyelesaian peliknya problematika kehidupan yang multidimensi dengan memadukan aspek spiritual, sosiokultural, dan pengetahuan dalam satu kendaraan perubahan melalui jalan pendidikan Islam yang proporsional, baik, dan benar. Di sisi lain, konseptualisasi yang dipahami sebagai formulasi konsep yang didasarkan pada hasil pengamatan di lapangan atau berdasarkan analisis deskriptif dari lintasan keilmuan yang relevan adapun performansi dalam hal ini dimaksudkan sebagai harapan terhadap konsepsi humanisme spiritual dari hasil proses ijtihad ilmiah yang kemudian dapat diimplementasikan dalam skala kecil, menengah, dan besar. Oleh karena itu, orientasi humanisme spiritual adalah manusia yang berpijak pada pemahaman teoantroposentris yang berimplikasi positif bagi keberlangsungan tata kelola kehidupan sosial, agama, dan

${ }^{1}$ Ali Mudhofir, Kamus Teori dan Aliran dalam Filsafat dan Teologi, (Yogyakarta: Gadjah Mada University Press, 1996), h. 92 
budaya. Di sisi lain, humanisme spiritual menghendaki adanya penghargaan dan penghormatan antar umat manusia secara universal yang dilandasi spiritualitas yang jernih dan pengetahuan keagamaan yang baik dan benar. ${ }^{2}$

\section{B. Humanisme Spiritual}

Manusia dengan segala kelebihan dan kekurangan yang melekat pada dirinya adalah makhluk sosial yang dijadikan Allah SWT khalifatu fi al-ardl untuk mengelola dan mengatur bumi ini secara proporsional serta untuk berkembang biak, menciptakan beragam inovasi produktif berasaskan kemaslahatan umat, memupuk dan menumbuhkan solidaritas lintas generasi, agama, suku dan golongan dalam wadah interaksi komunikatif berbasis kemanusiaan yang ramah, saling menghargai dan menghormati dalam bingkai perbedaan. Di sisi lain, manusia yang diciptakan oleh Allah SWT tidaklah sepenuhnya sebagai makhluk surgawi apalagi duniawi karena kedua aspek ini saling menyertai dalam diri manusia sebagai konsekuensi logis dari bani Adam. Mirandola dalam Hamidah menyatakan bahwa kemanusiaan tentunya harus menyertakan aspek kritis humanis dalam jiwa-jiwa yang teraliri nilai-nilai agama yang baik yang nantinya akan terpupuk sisi spiritualitas atau moralitas religius. $^{3}$

Humanisme yang seringkali dikampanyekan sekaligus dikonseptualisasikan oleh para cendekiawan sejatinya mengalami pasang surut diiringi kebingungan dan ketidakpastian mengenai ciri dari sosok manusia yang humanis. Hal ini diindikasikan melalui adanya perspektif yang berbeda di antara manusia mengenai aspek humanitas dirinya dalam mengelola pribadi dan lingkungannya. Seringkali dinyatakan bahwa bahwa manusia yang humanis adalah ia yang senantiasa menjunjung tinggi kemanusiaan yang memadukan

\footnotetext{
2 Hamidah Arafiani, "Humanisme Spiritual Sayyed Hossein Nasr Bagi Manusia Modern", Skripsi, (Yogyakarta: Fakultas Ushuluddin Dan Pemikiran Islam, 2017), h. 48-49

3 Ibid, h. 18.
} 
nilai-nilai ketuhanan yang penuh kasih sayang tanpa pilihan. Namun dalam realitanya pemahaman ini kadang kala menyingkirkan diri manusia sebagai motor penggerak humanisme dalam hal kemapanan psikis dan spiritual yang baik, artinya ketika manusia yang humanis mengimplementasikan konsep humanis dalam kehidupan sehari-hari haruslah dimulai dengan memanusiakan diri manusia tersebut dalam segala dimensi sehingga kesiapan ruhani dan fisik dalam pengalaman humanisme berjalan dengan landasan hati nurani baik dan kesiapan fisik yang maksimal.

\section{Humanisme Spiritual: Filosofi dan Konseptualisasi}

Manusia dalam perspektif filsafat adalah sebagai persona yang penuh dengan keunikan dalam berbagai dimensi. Keunikan yang dimiliki manusia tentunya memadu dengan sisi kerohaniaan yang fluktuatif dan tindak tutur yang kadangkala responsif. Individualitas yang merepresentasikan watak dan tabiat manusia juga didasarkan pada kualitas kehidupan yang mengatur dan mengirinya. Oleh karena itu, manusia menentukan kejiwaannya dalam ruang dan waktu yang ia tempati dan didapat sehingga keunikan-keunikan atau kekhasan manusia sebagai khalifatu fi al-ardl tentunya terletak pada dinamika atau pembaharuan yang direspon oleh keadaan atau latar yang menjadikannya sebagai manusia dengan segala melekat padanya.

Spiritualitas merupakan sumber dan keunikan atau kekhasan yang dimiliki manusia. Dalam diri manusia sisi spiritualitas memiliki arti penting karena hal ini menjadi penyangga sekaligus pengarah dalam kehidupan manusia yang didalamnya memuat beragam pelajaran yang tersirat maupun tersurat dalam aturan agama ataupun norma sosial dan budaya yang mengakar secara turun-temurun. Di sisi lain, spiritualitas yang terpupuk oleh siklus kegiatan ilmiah yang bersumber dari kajian-kajian keagamaan yang proporsional dan konstruktif-transformatif serta nilai-nilai sosial dan budaya yang terbentuk dalam konsensus suatu komunitas atau masyarakat 
merupakan penentu dan penunjang kreativitas, prestasi, dan ketaatan terhadap ajaran agama yang dianut dan diyakininya. ${ }^{4}$

Pancasila sebagai falsafah hidup berbangsa dan bernegara seluruh masyarakat Indonesia memiliki pandangan tersendiri mengenai manusia. Dalam falsafah pancasila dinyatakan bahwa manusia kesarwatunggalan atau monopluralisme dari keseluruhan unsurunsur hakikinya yang merupakan senyawaan kodrat monodualis: rajajiwa, memiliki sifat kodrat yang monodualis: makhluk individu-sosial, berkedudukan kodrat di hadapan Tuhan yang monodualis, yakni sebagai pribadi yang mandiri dan makhluk Tuhan sekaligus dan semuanya bersatu padu secara organis, harmonis, dan dinamis. Raga dalam konteks hal ini memiliki unsur tritunggal antara lain; anorganis, vegetatif, animal, sedangkan jiwa memiliki tridaya jiwa: cipta (untuk menangkap kebenaran dan kebaikan), rasa (untuk menangkap keindahan), dan karsa (untuk menangkap kebaikan). Maka, untuk memahami secara seksama mengenai hakikat pribadi manusia perspektif Pancasila dapat diperhatikan melalui diagram berikut ini; 5

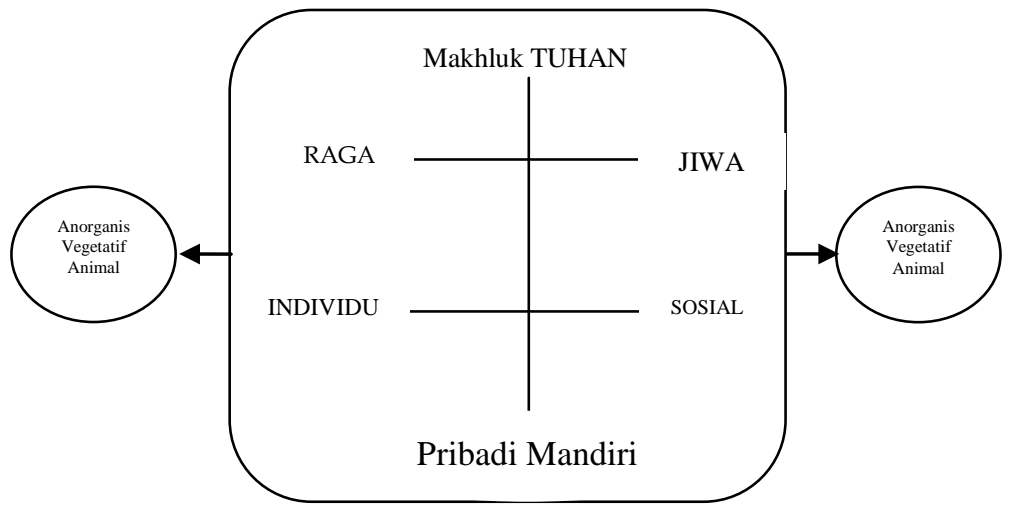

Skema Manusia dalam Perspektif Falsafah

Pancasila

4 Kasdin Sitohang, Filsafat Manusia Upaya Membangkitkan Humanisme, (Yogyakarta: Kanisius, 2009), h. 33

5 Sunarjo Wreksosuhardjo, Penerapan Ilmu Filsafat Pancasila Di Bidang Pendidikan, (Surakarta: UNS Press, 2007), h. 19 
Manusia dalam perspektif psikoanalisis memiliki konstruksi yang saling memadu dalam diri atau jiwa manusia tersebut. Psikoanalisis memberikan pandangan bahwa manusia adalah homo volens yang dipahami sebagai sosok makhluk hidup yang berakal dan memiliki hasrat dalam segala hal. Oleh karena itu, manusia dalam pandangan ini menjadikan interaksi, komunikasi, dan mensosialisasikan diri dalam dimensi yang lebih luas yakni dalam kehidupan berbangsa dan bernegara. Dalam melakukan ketiga proses tersebut manusia senantiasa mengoptimalkan komponen biologis yakni Id, ego, dan super ego yang didukung datu diiringi oleh aspek hewani, rasional, dan moral dalam bertindak tutur. ${ }^{6}$

Selain itu juga, al-Quran sebagai hudan li an-nās memiliki perspektif tersendiri mengenai manusia dengan didasarkan pada pemaknaan kata basyar, an-nās, al-insān, dan bani adam. Berikut ini tabel penjelasan mengenai keempat kata tersebut yang meliputi makna interpretatif yang nantinya dapat diorientasikan dalam kehidupan lelaku religius-spiritual dan normatif sosiokultural.

Tabel 1 Penafsiran Makna Manusia Dalam Al-Quran

\begin{tabular}{|c|c|c|}
\hline No & Kata & Penafsiran \\
\hline 1 & 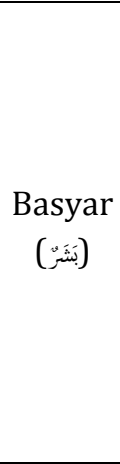 & $\begin{array}{l}\text { Secara etimologis kata basyar (ب) dipahami } \\
\text { sebagai ciptaan yang terbentuk secara fisik dan } \\
\text { tampak secara eksplisit. Kata basyar juga dipahami } \\
\text { sebagai golongan laki-laki dan perempuan yang } \\
\text { tercipta dengan kesempurnaan yang melekat } \\
\text { secara fisik dan tampak indah melalui beragam } \\
\text { pandangan.7 Selain itu, kata basyar menunjukkan } \\
\text { makhluk biologis dengan sifat-sifatnya seperti } \\
\text { makan, minum, melakukan hubungan seksual dan } \\
\text { aspek-aspek lainnya yang mengiringi. Oleh karena } \\
\text { itu, kata basyar dapat dipahami sebagai manusia }\end{array}$ \\
\hline
\end{tabular}

6 Ishak Hariyanto, "Pandangan Al-Quran Tentang Manusia", KOMUNIKE: Jurnal Ilmiah Komunikasi Penyiaran Islam, IAIN Mataram, Volume 7 No. 2 Desember 2015, h. 39

7 Jamaluddin Muhammad ibn Mandzūr al-Afriqi, Lisān Al-'Arab Mujallad Al-Rābi', (Bairut: Dār Shādir, tt), h. 59-60 


\begin{tabular}{|c|c|c|}
\hline & & 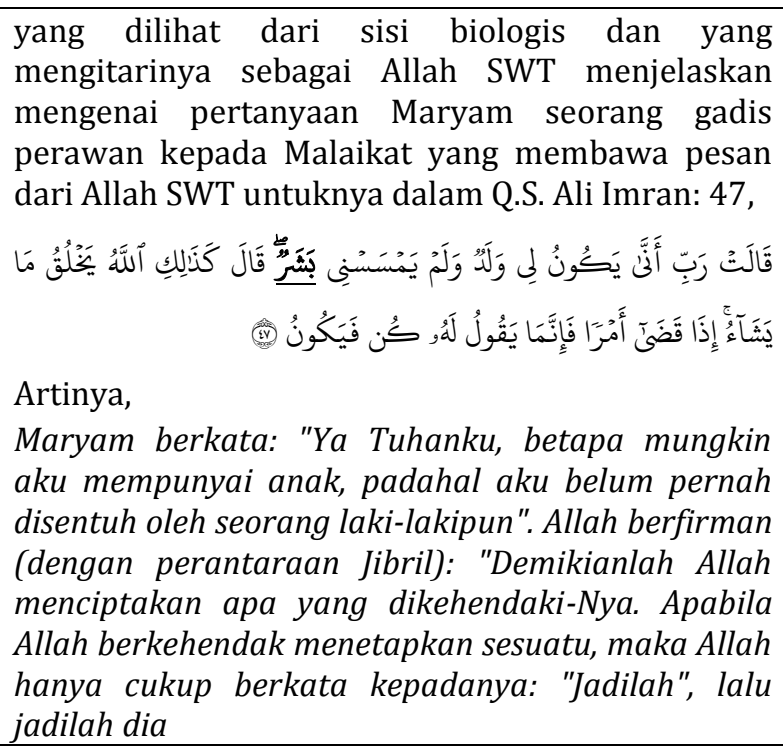 \\
\hline 2 & & $\begin{array}{l}\text { Kata insān memiliki tiga kategori pemahaman } \\
\text { pertama, manusia memiliki keistimewaan yang } \\
\text { terletak dalam sistem kognisi dan afeksi yang } \\
\text { saling memadu dalam perjalanan kehidupannya } \\
\text { untuk memikul amanah sebagai khalifatu fi al-ardl. } \\
\text { Kedua, manusia dalam lelaku hidupnya senantiasa } \\
\text { direlasikan dengan predisposisi yakni kecende- } \\
\text { rungan untuk menerima atau menolak sesuatu } \\
\text { berdasarkan pengalaman dan norma yang di } \\
\text { milikinya baik secara negatif dan positif yang } \\
\text { inheren. Ketiga, kata insān direlasikan dengan } \\
\text { proses kejadian manusia secara dinamis dan } \\
\text { memadukan aspek jasmani dan rohani. Adapun } \\
\text { yang membedakan antara sesama manusia adalah } \\
\text { terletak pada aspek kecerdasan, fisik, dan } \\
\text { mentalitas yang dipupuk semenjak ia lahir ke } \\
\text { dunia. }\end{array}$ \\
\hline 3 & $\begin{array}{c}\text { An-nās } \\
\text { (النَاشُ) }\end{array}$ & $\begin{array}{l}\text { Kata an-nās yang berarti manusia dimaknai } \\
\text { sebagai wujud eksistensinya sebagai makhluk } \\
\text { sosial secara universal tanpa mendikotomikan sisi } \\
\text { keimanan atau kekafiran dan seluruhnya }\end{array}$ \\
\hline
\end{tabular}




\begin{tabular}{|c|c|c|}
\hline & & $\begin{array}{l}\text { menunjukkan kepada satu keturunan yakni bani } \\
\text { Adam. } .^{8} \text { Oleh karena itu, melalui kata ini Allah SWT } \\
\text { ingin menjadikan manusia sebagai partner hidup } \\
\text { bagi siapapun karena manusia sebagai makhluk } \\
\text { sosial sejatinya hidup dalam lingkup masyarakat } \\
\text { yang majemuk dalam segala bidang dan bersama- } \\
\text { sama membangun peradaban unggul dan ber- } \\
\text { martabat. }\end{array}$ \\
\hline 4 & $\begin{array}{c}\text { Bani Adam } \\
\text { (تبني آدَم) }\end{array}$ & $\begin{array}{l}\text { Maksud bani Adam (َّ) dalam al-Quran adalah } \\
\text { sebagai satu pertalian keturunan dari Nabi Adam } \\
\text { Alaihi Salām. Bani Adam dalam pemahamannya } \\
\text { menghendaki adanya konsep persaudaraan dalam } \\
\text { lintas generasi, golongan, suku, agama, dan lain } \\
\text { sebagainya yang berimplikasi pada persatuan dan } \\
\text { persamaan dalam naungan umat manusia. }{ }^{9}\end{array}$ \\
\hline
\end{tabular}

Tabel penjelasan tersebut dapat direlasikan dengan pernyataan bahwa manusia yang beragama menurut Sayyed Hosen Nasr tentunya harus memiliki dorongan kuat untuk mentransendensikan dirinya dalam lingkup dorongan spiritualitas individual maupun kolektif. Manusia juga makhluk spiritual tentunya menjadikan keyakinan terhadap Tuhannya sebagai kebutuhan mutlak kejiwaannya dalam dimensi ritual maupun interaksi secara horizontal. Oleh karena itu, dapat dipastikan bahwa eksistensi agama di tengah-tengah arus modernisasi zaman adalah terletak pada kekuatan spiritual pemeluknya dalam siklus kehidupan beragamanya dalam proses beribadah secara sempit maupun luas. Di sisi lain, musuh penghancur spiritualitas dalam diri manusia adalah terletak pada siklus kehidupan yang tidak sehat secara rohani maupun jasmani dapat menjadi momok bagi mereka yang menjadikan spiritualitas sebagai puncak ketenangan hidup.

${ }^{8}$ M. Quraish Shihab, Wawasan Al-Quran Tafsir Maudu'i Atas Pelbagai Persoalan Umat, (Bandung: Mizan, 2007), h. 281

9 Rahmi Danis, "Falsafah Manusia Dalam Al-Quran", SIPAKALEBBI: Jurnal Kesetaraan Gender,Pemberdayaan, Kesejahteraan, dan Pencegahan Kekerasan Pada Anak Dalam Konteks Keagamaan dan Budaya, UIN Alaudin Makasar, Volume 1 Nomor 2 Desember 2014, h. 206 
Humanisme dalam konsepsi setiap individu tentunya merujuk pada sisi harkat dan martabat manusia dalam menjalani kehidupannya. Roger L. Shin dalam Basman menyatakan bahwa humanisme yang kini menyelinap dalam benak setiap orang dan mengakar sebagai aliran oleh mereka para penggiat isu-isu kemanusiaan merupakan penghargaan terhadap manusia dan nilainilai kehidupan yang dianut dan diamalkannya dalam roda kehidupan umat manusia. Humanisme sejatinya menghormati dan menghargai umat manusia dengan sepenuhnya sebagai jiwa yang memiliki beragam potensi.

Selain itu juga, humanisme sebagai aliran dan pemahaman tentunya memperhatikan secara seksama problematika kemanusiaan dan solusi konkret dalam penanganannya sekaligus mendorong atau memotivasi mereka untuk mengekspresikan potensi kemanusiaan yang positif untuk menjaga stabilitas kedamaian jasmani dan rohani, kemapanan pengetahuan yang dipelajari, sikap keberagamaan yang menggiring ke dalam suasana kesejukan, keindahan dan keharmonisan, serta kemampuan mengendalikan dan menilai diri setiap manusia dalam beragam keadaan didasarkan pada fluktuasi kejiwaan yang dijumpai. Oleh karena itu, humanisme akan senantiasa berwarna apapun namun harus berada dalam kerangka saling menghormati, menghargai, dan menyayangi umat manusia. ${ }^{10}$

Berbeda dengan Humanisme yang dipahami oleh J.A. Symon, Ia menyatakan bahwa humanisme sejatinya merupakan perlawanan diri manusia terhadap despotisme ajaran agama yang secara praksis kadang kala menyulitkan dan mengenyampingkan sisi kondisional seorang manusia. Symon juga menekankan pentingnya akal pikiran sebagai dasar dialektika kehidupan manusia dengan lingkungan sosial dan budayanya. Oleh karena itu, aspek sekuler dari pemahaman humanisme oleh Symon menjadi kendaraan dalam mengeksistensikan manusia dalam berbagai dimensi kehidupan. Symon melalui gagasan

10 Basman, "Humanisme Islam: Studi Terhadap Pemikiran Ali Syari'ati", Disertasi (Yogyakarta: Program Pascasarjana UIN Sunan Kalijaga, 2007), h. 28 
humanisme sekulernya tentunya akan berimplikasi pada pemisahan secara eksplisit antara ajaran-ajaran agama dengan norma-norma kehidupan yang ditentukan atau diatur oleh sistem dan konsensus dari suatu komunitas atau masyarakat. ${ }^{11}$

Humanisme secara filosofis merupakan representasi dari kreativitas keilmuan yang dipelajari dan dipraktekkan oleh manusia serta sisi keagamaan saintifik-fungsional dari pemeluk agama di kehidupan sehari-hari. Di sisi lain, aspek historisitas kemanusiaan yang hadir secara turun-temurun tentunya berimplikasi pada gerakan-gerakan struktural yang mengetengahkan isu-isu krusial dan mutakhir di bidang humaniora. Amin Abdullah dalam Hamidah menyatakan bahwa sisi humanis manusia dapat dilihat dari proses beragama yang tidak hanya sebatas aspek transendensi yang tinggi namun pemuliaan dan pemenuhan kebutuhan-kebutuhan kemanusiaan yang dapat menciptakan kestabilan, kesejahteraan dan kedamaian hidup yang terus menerus.

Humanisme religius menjadi pintu masuknya pemahaman dan pengamalan humanisme spiritual dalam diri setiap pemeluk agama. Bagi seorang muslim spiritualitas dalam Islam tentunya didukung dengan aspek transendensi yang dijelaskan oleh Allah SWT dalam kitab-Nya yang agung al-Quran al-Karīm dan diimbangi pemahaman dan penjelasan as-Sunnah yang baik. Humanisme sebagai paham atau aliran yang dimunculkan pada masa Renaissance yakni abad ke-16 yang terjadi di Italia. Paham ini bercorak neoplatonis yang berkolaborasi antara keyakinan religius yang mapan dalam sisi mistisisme suatu agama. Adapun dalam konteks ajaran Islam dapat diintepretasikan sebagai keyakinan terhadap Allah SWT sebagai Tuhan bagi semesta Alam dan ajaran-ajaran-Nya yang hanif di bawah dan disebarluaskan oleh rasul-Nya yang agung Muhammad Saw. ${ }^{12}$

Konsep humanisme neoplatonik yang muncul pada masa Renaissance menekankan pada konsepsi atas fisik manusia berupa

\footnotetext{
11 Ibid, h. 31

12 Bambang Sugiharto, edit., Humanisme dan Humaniora Relevansinya Bagi Pendidikan, (Yogyakarta: Jalasutra, 2008), h. 50
} 
materi yang kemudian dilanjutkan pada konsepsi rohaniah yang menjadi motor penggerak kehidupan manusia tersebut. Oleh karena itu, apabila manusia mengelola dengan baik tubuhnya secara keseluruhan dengan teratur dan berasaskan nilai-nilai religius maka kesempurnaan fisik manusia tersebut dapat mencerminkan keindahan pola hidupnya dan kearifan budi dalam tindak tuturnya. ${ }^{13}$

Ketika humanisme menjadi landasan etis tindak tutur setiap manusia, maka sudah sepantasnya manusia akan menjadi sosok makhluk yang berakhlak al-karimah. Di sisi lain, humanisme hendaknya dapat dijadikan konsep berperilaku setiap manusia dalam hal keterbukaan terhadap prinsip-prinsip yang diciptakan atau dianut oleh orang lain. Dengan maksud bahwa ketika seseorang bermuamalah dalam kehidupan sehar-hari ia akan senantiasa memiliki kepedulian terhadap orang lain, menumbuhkan sikap kasih sayang kepada siapapun yang melampaui sekat-sekat primordial yang kadangkala mengikat atau menjerat bagi setiap individu. Oleh karena itu, humanisme akan berimplikasi pada sikap egaliter dalam menjalani kehidupan yang majemuk dalam segala hal, kasih sayang yang mendamaikan dan menyejukkan, dan cinta akan keadilan dalam berbagai dimensi. ${ }^{14}$

Konsepsi Nasr mengenai manusia dalam dimensi yang utuh adalah fitrah atau sifat manusia yang memiliki kedalaman sisi kebatinan dan intelegensi yang terasah dan terdorong oleh aspek lainnya. Ketika dua aspek tersebut saling memadu dalam pencarian jati diri manusia sebagai makhluk multidimensi yang juga berkewajiban untuk beribadah secara luas maka, jalan humanisme spiritual akan mendapati landasan teoritik dan pedoman prakteknya yang didorong oleh adanya sumbangsih kosmos, manusia, dan Tuhan Yang Maha Kuasa beserta kitab suci-Nya yang haq al-qurān al-karīm. Oleh karena itu, humanisme spiritual yang berasaskan keislaman adalah

13 Ibid, h. 53

14 Franzs Magnis Suseno, Humanisme Relegius vs Humanisme Sekuler ?, dalam Islam dan Humanisme Aktualisasi Humanisme Islam di Tengah Krisis Humanisme Universal, (Yogyakarta: Pustaka Pelajar, 2007), h. 212 
perwujudan ketaatan kepada Sang Khaliq Allah SWT dan Rasul-Nya yang Agung dalam proses memanusiakan seluruh manusia dalam beragam dimensi kehidupan. Bagi mereka yang mengingkari itu semua sejatinya adalah pengingkaran yang diciptakan oleh psikis dan bukan jasmani. Karena jasmani hanyalah instrumen dan wadah psikis yang sering bergejolak dalam ruang dan waktu. Oleh karena itu, penciptaan stabilitas psikis menjadi program terpenting bagi kelangsungan humanisme spiritual dalam diri setiap manusia.

\section{Humanisme Spiritual Dalam Praksis Pendidikan Islam}

Spiritualitas Islam tentunya menjadi cerminan lahir dan batin seorang muslim yang menyeimbangkan sisi duniawi dan ukhrawi dalam lelaku suci seorang hamba ('abdullah) dalam melangsungkan kehidupannya yang kompleks oleh segala hal. Spiritualitas yang kokoh didorong oleh adanya kualitas keimanan, ketaqwaan dan pengetahuan yang cemerlang dalam putaran ritual keagamaan, tindak tutur yang positif di kehidupan sehari-hari, dan pola pikir yang terbuka serta responsif positif terhadap perubahan zaman. Manusia sebagai makhluk eksentris yang senantiasa beraktualisasi dalam beragam dimensi yang ia ingini dan dibawa oleh naluri jasadi serta rohani. Eksistensi manusia dalam dunia nyata tentunya merefleksikan sisi kebatinan yang fluktuatif agar dapat diisi oleh sisi kebatinan lainnya dari alam. Ketika intuisi positif manusia berangkat dari refleksi kehidupan multidimensi tentunya ini menjadi bahan kajian yang secara berkesinambungan akan menampak secara eksplisit dalam bentuk beragam produksi kreativitas dari soft skill atau hard skill15.

Spiritualitas yang dipupuk dan dijadikan landasan kehidupan manusia tentunya diawali dengan kenyataan bahwa ketika manusia berpikir, berbudaya, beragama, dan bersosialisasi dengan khalayak umum maka, tentunya antara jasmani dan rohani adalah suatu hal yang integralistik untuk menggerakkan semua itu untuk menuju satu ruang yang berharga yakni spiritualitas manusia. Di sisi lain pula

15 Adelbert Snijders, Antropologi Manusia Paradoks Dan Seruan, (Yogyakarta: Kanisius, 2004), h. 15 
dinyatakan bahwa sisi kerohaniaan manusia dapat direfleksikan melalui sistem kerja fisik yang beraturan atau tidak beraturan yang dalam hal ini tersentuh oleh sisi mistisisme agama yang menyertai. Seperti halnya seseorang dalam ritual keagamaan atau perilaku kesalehan lainnya yang didorong oleh ajaran-ajaran agama yang haniff akan memperlihatkan sisi kerohaniaan dalam realita kehidupan. ${ }^{16}$

Kecerdasan spiritual menjadi lokomatif kemapanan kejiwaan manusia dalam menjalani kehidupan dalam gerbong masyarakat yang majemuk. Kecerdasan ini penting untuk direalisasikan dalam diri atau jiwa manusia untuk menjadi penopang kejumudan-kejumudan ekstrem yang tercipta oleh suasana yang tak beraturan akibat kesalahan-kesalahan sistemik ataupun berawal dari kondisi yang kurang memadai. Kecerdasan spiritual sejatinya berdikari dalam jiwa manusia yang berasaskan kearifan di luar ego atau pikiran sadar. Ketika manusia mengoptimalkan kecerdasan spiritualnya, maka halhal yang membuatnya menjadi lebih spritualis akan dibutuhkan dan menjadi konsumsi jiwa terus menerus untuk menjadikan dirinya sebagai makhluk sosial yang bermanfaat dan berguna bagi siapapun. Oleh karena itu, melalui kecerdasan spiritual manusia diharapkan mampu memperoleh nilai-nilai baru dalam kehidupannya yang tentunya nilai-nilai tersebut merupakan sari pati dari nilai-nilai yang terbentuk oleh konsensus masyarakat maupun ajaran agama melalui syariatnya yang $\underline{h} a n i \bar{f} .17$

Pendidikan Islam secara umum dipahami sebagai pertama, tarbiyah yakni proses pengasuhan, perbaikan, dan mengarahkan kehidupan setiap siswa secara baik dan benar berdasarkan norma sosial dan agama. Kedua, ta'dib yakni proses internalisasi karakterkarakter keagamaan yang baik, nilai-nilai sosial-budaya yang mewujud dalam kehidupan bermasyarakat. Selain itu juga, konsep ta'dib yang di bangun tentunya diarahkan kepada sisi penguatan spiritualitas yang baik dalam dimensi pengakuan keesaan dan

16 Ibid, h. 108

17 Danah Zohar dan Ian Marshal, SQ Kecerdasan Spiritual, (Bandung: Mizan, 2007), h. 8 
keagungan Allah SWT penguasa semesta alam. Ketiga, ta'līm yakni proses transmisi keilmuan dari transmiter (guru) kepada setiap siswa dalam kegiatan belajar dan mengajar di kelas. Adapun dalam implementasikan konsep ta'līm tentunya harus memadukan unsur keilmuan kesemestaan, al-Quran dan As-Sunnah sebagai landasan teoritik keilmuan, dan isu-isu kritis dan mutakhir dalam kehidupan sebagai ladang observasi, identifikasi, dan formulasi yang inovatif dan akomodatif terhadap tuntutan dan perubahan zaman ${ }^{18}$. Oleh karena itu, pendidikan Islam tentunya harus berbentuk perwujudkan nilainilai keislaman yang hanīf dan kokoh dalam proses pendidikan dengan memadukan aspek ontologis yakni hakikat ajaran Islam yang tertuang dalam al-Quran dan as-Sunnah, aspek epistemologis ajaran Islam yang memadukan sumber pengetahuan, pengolahan dan pengkajian pengetahuan yang relevan dengan zamannya, dan pengujian pengetahuan yang telah dipelajari melalui laboratorium kehidupan yakni masyarakat atau sekolah pada khususnya, serta aspek aksiologis yakni proses implementasi nilai-nilai yang telah dikonseptualisasikan sehingga memiliki harga yang berkualitas dan penuh kebermaknaan bagi kehidupan individu maupun kelompok. ${ }^{19}$

Pendidikan Islam tentunya menjadi pintu masuk penguatan humanisme spiritual yang dipraktekkan dalam kehidupan sekolah meliputi aspek pembelajaran, interaksi sosial, dan praktek keagamaan yang dikondisikan. Aspek keagamaan yang menjadi penopang humanisme spiritual seorang siswa dapat ditekankan melalui dimensi religiusitas yang kokoh, karena sejatinya spiritualitas tersebut tumbuh dan berkembang seiring kualitas religiusitas yang siswa miliki. Meskipun pada dasarnya spiritualitas terwujud dari serangkaian pengalaman universal yang diperoleh individu dari perjalanan dari satu kehidupan ke kehidupan lainnya. Oleh karena itu, spiritualitas yang menghantarkan seseorang menjadi manusia yang menghormati

18 Abdul Mujib dan Jusuf Mudzakkir, Ilmu Pendidikan Islam, (Jakarta: Kencana Prenada Media, 2006), h. 10-21

19 Tobroni, Pendidikan Islam Paradigma Teologis, Filosofis, dan Spiritual, (Malang: UMM Press, 2008), h. 21-25 
dan menghargai manusia lainnya dapat di temui dalam setiap segi dan aspek kehidupan yang dijalani. Life experience is the best teacher menjadi lokomotif bangunan spiritualitas seseorang.

Sekolah atau madrasah sebagai wadah pendidikan Islam untuk ditransmisikan harus menempatkan humanisme spiritual dalam level teoritik dan konsepsi pragmatik di kehidupan nyata. Problematika manusia modern dalam penentuan dan pengembalian wujud spiritualitas yang hilang tentunya dapat direspon kuat oleh materimateri ilmiah yang termaktub dalam keilmuan pendidikan Islam seperti penguatan konsepsi Ketuhanan yang baik, keislaman yang responsif dan transformatif, fiqh kehidupan Islami yang rahmatan lil'alamin, dan al-akhlāk al-karīmah yang termanifestasi dalam kesalehan sosial. Oleh karena itu, untuk meng-implementasikan konsep humanisme spiritual dalam level pendidikan Islam diperlukan pernyataan-pernyataan penting yang dielaborasikan dengan proses pendidikan Islam di sekolah di madrasah melalui tabel penjelasan berikut ini;

Tabel 2

Konsep Humanisme Spiritual dan Implementasinya dalam Pendidikan Islam

\begin{tabular}{|c|c|c|}
\hline No & Humanisme Spiritual & Implementasi dalam Pendidikan Islam \\
\hline 1 & $\begin{array}{l}\text { Manusia bertanggung jawab } \\
\text { terhadap transendensi yang ia } \\
\text { miliki dan mempercayainya dalam } \\
\text { dimensi ibadah skala kecil dan } \\
\text { besar }\end{array}$ & $\begin{array}{l}\text { Penguatan materi ketauhidan atau } \\
\text { pembelajaran aqidah Islamiyyah yang } \\
\text { benar berdasarkan al-Quran dan as- } \\
\text { Sunnah. Pemahaman mengenai Tauhid } \\
\text { fungsional yakni pengejawantahan sifat- } \\
\text { sifat ketuhanan yang haq dalam diri } \\
\text { setiap individu berbentuk tindak tutur } \\
\text { yang berdasarkan norma-norma agama } \\
\text { yang baik dan benar. }\end{array}$ \\
\hline 2 & $\begin{array}{l}\text { Percaya pada hal-hal yang bersifat } \\
\text { eskatologis }\end{array}$ & $\begin{array}{l}\text { Penguatan serta pengokohan keimanan } \\
\text { dan ketaqwaan melalui program- } \\
\text { program edukatif dan religius yang } \\
\text { difasilitasi oleh kelompok diskusi } \\
\text { keagamaan yang didalamnya mengkaji } \\
\text { beragam referensi keislaman yang baik, } \\
\text { menyelenggarakan ritual-ritual keagam- } \\
\text { aan secara kolektif untuk mendorong }\end{array}$ \\
\hline
\end{tabular}




\begin{tabular}{|c|c|c|}
\hline & & $\begin{array}{l}\text { sisi spiritualitas yang baik dalam diri } \\
\text { setiap individu. }\end{array}$ \\
\hline 3 & $\begin{array}{l}\text { Manusia sebagai hamba Allah SWT } \\
\text { yang bertugas mengelola dan } \\
\text { menjaga kelestarian alam }\end{array}$ & $\begin{array}{l}\text { Memahami secara seksama tentang alam } \\
\text { semesta melalui kajian komprehensif } \\
\text { studi al-Quran dan kajian-kajian } \\
\text { mendalam dari referensi-referensi } \\
\text { keislaman yang akurat. Implementasi } \\
\text { nilai-nilai ajaran Islam dalam tindak } \\
\text { tutur kehidupan sehari-hari meliputi } \\
\text { sikap gotong royong, saling } \\
\text { menghormati antar sesama atau } \\
\text { berlainan umat beragama, menjaga } \\
\text { stabilitas kenyamanan dan kedamaian } \\
\text { setiap batin para pemeluk agama dari } \\
\text { beragam kegiatan-kegiatan yang dapat } \\
\text { meruntuhkan bangunan solidaritas dan } \\
\text { memutuskan tali persaudaraan dalam } \\
\text { bingkai kemajemukan di segala bidang. }\end{array}$ \\
\hline 4 & $\begin{array}{l}\text { Rasionalitas yang manusia ciptakan } \\
\text { bukanlah menjadi otoritas utama, } \\
\text { melainkan perpaduan antara } \\
\text { kebatinan dan pikiran yang sehat } \\
\text { dan jernih menjadi pendorong } \\
\text { stabilitas kejiwaan manusia }\end{array}$ & $\begin{array}{l}\text { Menciptakan ruang dialog keagamaan } \\
\text { yang sehat, dinamis, dan responsif } \\
\text { dengan memperhatikan aspek kondisi } \\
\text { dan realitas yang terjadi dalam diri } \\
\text { individu dan masyarakat pada } \\
\text { umumnya. Menjadikan nilai-nilai ajaran } \\
\text { agama yang hanif sebagai fondasi } \\
\text { penyelesaian beragam problematika } \\
\text { kehidupan yang muncul ke permukaan. }\end{array}$ \\
\hline 5 & $\begin{array}{l}\text { Manusia harus kembali ke } \\
\text { potensial spiritualnya dan } \\
\text { kemanusiaannya }\end{array}$ & $\begin{array}{l}\text { Mensinergikan ritual-ritual keagamaan } \\
\text { dengan rangkaian perbuatan yang } \\
\text { mencerminkan hasil ritual keagamaan } \\
\text { tersebut dalam dimensi kehidupan yang } \\
\text { lebih luas }\end{array}$ \\
\hline 6 & $\begin{array}{l}\text { Menghormati dan menghargai } \\
\text { manusia secara lahiriah dan } \\
\text { batiniahnya }\end{array}$ & $\begin{array}{l}\text { Mengajarkan sikap husnudzan dalam } \\
\text { pergaulan sehari-hari di lingkungan } \\
\text { masyarakat, menjaga suasana kebatinan } \\
\text { secara universal melalui sikap-sikap } \\
\text { yang mendamaikan dan menyejukkan } \\
\text { setiap insan beragama, serta mampu } \\
\text { dengan semaksimal mungkin untuk } \\
\text { dapat mengendalikan diri dari beragam } \\
\text { dorongan yang dapat meruntuhkan dan } \\
\text { memutuskan persaudaraan umat } \\
\text { manusia. }\end{array}$ \\
\hline 7 & $\begin{array}{l}\text { Humanis spiritual bersifat } \\
\text { teomorfisme yakni berkiblat pada } \\
\text { sifat-sifat ketuhanan }\end{array}$ & $\begin{array}{l}\text { Mewujudkan konsepsi manusia yang } \\
\text { beriman senantiasa menjunjung tinggi } \\
\text { martabat umat manusia dalam diri } \\
\text { setiap pembelajar dan }\end{array}$ \\
\hline
\end{tabular}




\begin{tabular}{|l|l|}
\hline & mengejawantahkan sifat-sifat ketuhanan \\
& yang universal dalam diri setiap mukmin \\
& dan muttaqin sehingga tercipta suasana \\
& kebatinan umat manusia dengan tenang, \\
& damai, dan bahagia. \\
\hline
\end{tabular}

\section{Kesimpulan}

Berdasarkan uraian di atas, maka dapat penulis simpulkan bahwa humanisme secara filosofis merupakan representasi dari kreativitas keilmuan yang dipelajari dan dipraktekkan oleh manusia serta sisi keagamaan saintifik-fungsional dari pemeluk agama di kehidupan sehari-hari. Spiritualitas merupakan sumber dan keunikan atau kekhasan yang dimiliki manusia. Pada diri manusia sisi spiritualitas memiliki arti penting karena hal ini menjadi penyangga sekaligus pengarah dalam kehidupan manusia yang didalamnya memuat beragam pelajaran yang tersirat maupun tersurat dalam aturan agama ataupun norma sosial dan budaya yang mengakar secara turuntemurun.

Humanisme spiritiual merupakan konsep bangunan kemanusiaan yang berkiblat pada lini teoantroposentris yakni menjadikan aspek ketuhanan dengan segala kemahaannya dan manusia dengan potensi yang dimilikinya untuk menjadikannya lebih berarti dan bermakna dalam perjalanan kehidupan yang semakin kompleks rintangannya.[]

\section{Daftar Pustaka}

Abdul Mujib dan Jusuf Mudzakkir, Ilmu Pendidikan Islam, Jakarta: Kencana Prenada Media, 2006.

Arafiani, Hamidah, Humanisme Spiritual Sayyed Hossein Nasr Bagi Manusia Modern, skripsi Yogyakarta: Fakultas Ushuluddin Dan Pemikiran Islam, 2017.

Bambang Sugiharto, edit., Humanisme dan Humaniora Relevansinya Bagi Pendidikan, Yogyakarta: Jalasutra, 2008. 
Basman, Humanisme Islam: Studi Terhadap Pemikiran Ali Syari'ati, disertasi Yogyakarta: Program Pascasarjana UIN Sunan Kalijaga, 2007.

Danah Zohar dan Ian Marshal, SQ Kecerdasan Spiritual, Bandung: Mizan, 2007.

Franzs Magnis Suseno, Humanisme Relegius vs Humanisme Sekuler ?, dalam Islam dan Humanisme Aktualisasi Humanisme Islam di Tengah Krisis Humanisme Universal, Yogyakarta: Pustaka Pelajar, 2007

Ibn Mandzūr al-Afriqi, Jamaluddin Muhammad, Lisān Al-'Arab Mujallad Al-Rābi', Bairut: Dār Shādir, tt.

Ishak Hariyanto, "Pandangan Al-Quran Tentang Manusia, "KOMUNIKE: Jurnal Ilmiah Komunikasi Penyiaran Islam, IAIN Mataram, Volume 7 Nomor 2 Desember 2015

Mudhofir, Ali, Kamus Teori dan Aliran dalam Filsafat dan Teologi, Yogyakarta: Gadjah Mada University Press, 1996.

Rahmi Danis, "Falsafah Manusia Dalam Al-Quran", SIPAKALEBBI: Jurnal Kesetaraan Gender, Pemberdayaan, Kesejahteraan, dan Pencegahan Kekerasan Pada Anak Dalam Konteks Keagamaan dan Budaya, UIN Alaudin Makasar, Volume 1 Nomor 2 Desember 2014

Shihab, M. Quraish, Wawasan Al-Quran Tafsir Maudu'i Atas Pelbagai Persoalan Umat, Bandung: Mizan, 2007.

Sitohang, Kasdin, Filsafat Manusia Upaya Membangkitkan Humanisme, Yogyakarta: Kanisius, 2009.

Snijders, Adelbert, Antropologi Manusia Paradoks Dan Seruan, Yogyakarta: Kanisius, 2004.

Tobroni, Pendidikan Islam Paradigma Teologis, Filosofis, dan Spiritual, Malang: UMM Press, 2008. 
Wreksosuhardjo, Sunarjo, Penerapan Ilmu Filsafat Pancasila Di Bidang Pendidikan, Surakarta: UNS Press, 2007. 